\title{
Life in extraordinary concentrations (a tribute to Peter Beuge)
}

\author{
Jörg Matschullat
}

\begin{abstract}
Background: Our growing humankind needs fertile soils for its sustainable development. Population growth and related use of resources, jointly with environmental pollution seem to contradict that demand. Recently available geochemical atlases allow for a better assessment of representative soil chemistry and potential pollution status, and thus for more efficient planning and development.

Results: Despite millennia of human soil use (agriculture and forestry) and perceived abuse (mining etc.), most of Europe's soils are on the continental scale more strongly influenced by natural forces (primarily geology/lithology) than by human impact. Even in large conurbations (e.g., Berlin), baseline values can be encountered in the city centre and in spatial proximity to highly contaminated sites. In a country like Brazil, where significant human impact started only about 500 years ago, challenges appear more demanding, due to the very old age of most soils and a radical depletion of nutrients. Yet, relatively recent site-specific to local contamination appears almost negligible in comparison, again corroborating the dominant role of natural forces and processes (geology, climate). Both regions, representing significant northern and southern hemispheric conditions, show for most chemical elements a very wide natural concentration range.

Conclusions: The objective necessity to clean up polluted sites and to avoid additional soil pollution can be strongly supported by acknowledging the highly localized true contamination of soils. Related governmental regulations (threshold values etc.) should be applied with a deeper understanding for natural variability and for real risks involved in positive pedogeochemical anomalies, thus saving money and frustration.
\end{abstract}

Keywords: Pedogeochemistry, Threshold values, Background or baseline values, Europe, Brazil, Australia

\section{Background}

Soil protection is one of the global challenges to be met by the growing humankind. The topic is partly directly related to further world population growth; at least to the mid $21^{\text {st }}$ Century, when 9 billion people are expected to populate the planet [1]. The term "soil protection", in analogy to "species protection, water and climate protection" already suggests that this basic life-sustaining resource is under pressure. The book "Dirt" by [2], vividly illustrates these pressures, their causes and historical development, and shows pathways to solutions. Yet, major misperceptions persist not only amongst laypeople, when it comes to soil pollution issues. Various places exist -

Correspondence: joerg.matschullat@ioez.tu-freiberg.de Interdisciplinary Environmental Research Centre, TU Bergakademie Freiberg, Brennhausgasse 14, D-09599, Freiberg, Germany the county of Freiberg, Saxony, Germany, is one of them - where centuries of metal mining and smelting history have left a legacy that, seen through the eyes of regulators, are not fit for sustaining healthy human life. That motivates the title of this contribution, which is a quote from my deceased colleague and predecessor Peter Beuge, professor of Geochemistry at TU Bergakademie Freiberg, who contributed significantly to the topic.

A widespread perception sees a detrimental large-scale contamination of soils, particularly in industrial countries. This paper compares two regions of almost similar size, representing the northern hemisphere and partly dense industrial legacy (Europe) and the southern hemisphere with limited industrial history (Brazil, and some data from Australia). This contribution focuses on inorganic components. Yet, the key hypotheses are conferrable to

\section{空}


organics - with the major difference that the latter show partly much shorter soil retention times due to metabolic decay.

The following two key hypotheses are being discussed:

- Relevant (for ecosystems, human health), human triggered soil contamination does not occur ubiquitously, but is largely highly locally focused (Table 1; Figures 1 and 2) - an important starting point for constructive solutions,

- The soil chemistry of Europe as an example for the mostly temperate humid climate zone is distinctively different from those in (sub)tropical regions (e.g., Brazil).

Screening modern geochemical atlases (e.g., [3,4]) shows the rather widespread concentration range of major, minor and trace elements (see Table 2 with selected examples for trace elements). At the chosen spatial scale only a rather small part of the observed particularly high concentrations can be identified as anthropogenic anomalies and thus true soil contamination. "High" element concentrations do not necessarily reflect contamination, but may point at natural mineralization. The arguments intend to put the topic soil protection into perspective. This is needed to assess any issue more precisely and to prioritize issues; a prerequisite to successfully tackle the challenges in a more appropriate and problem-oriented manner. This includes using a unified and precise spatial scale (currently missing), which is being introduced in Table 1 [5].

Table 1 Recommended nomenclature for spatial scales

\begin{tabular}{|c|c|c|}
\hline Unit & Sub-unit & Dimension (area) \\
\hline Global & supra-continental & $50-500$ Mio. $\mathrm{km}^{2}$ \\
\hline \multirow[t]{2}{*}{ Continental } & continental & $5-50 \mathrm{Mio} \mathrm{km}^{2}$ \\
\hline & sub-continental & $0.5-5 \mathrm{Mio} \mathrm{km}^{2}$ \\
\hline \multirow[t]{3}{*}{ Regional } & supra-regional & $50,000-500,000 \mathrm{~km}^{2}$ \\
\hline & regional & $5,000-50,000 \mathrm{~km}^{2}$ \\
\hline & sub-regional & $500-5,000 \mathrm{~km}^{2}$ \\
\hline \multirow[t]{3}{*}{ Local } & supra-local & $50-500 \mathrm{~km}^{2}$ \\
\hline & local & $5-50 \mathrm{~km}^{2}$ \\
\hline & sub-local & $0.5-5 \mathrm{~km}^{2}$ \\
\hline \multirow[t]{3}{*}{ Site } & supra-site & $50,000 \mathrm{~m}^{2}-0.5 \mathrm{~km}^{2}$ \\
\hline & site & $5,000-50,000 \mathrm{~m}^{2}$ \\
\hline & sub-site & $500-5,000 m^{2}$ \\
\hline \multirow[t]{3}{*}{ Spot } & supra-spot & $50-500 m^{2}$ \\
\hline & spot & $5-50 m^{2}$ \\
\hline & sub-spot & $0.5-5 \mathrm{~m}^{2}$ \\
\hline \multirow[t]{3}{*}{ Point } & supra-point & $500 \mathrm{~cm}^{2}-0.5 \mathrm{~m}^{2}$ \\
\hline & point & $50-500 \mathrm{~cm}^{2}$ \\
\hline & sub-point & $5 \mathrm{~cm}^{2}-50 \mathrm{~cm}^{2}$ \\
\hline
\end{tabular}

\section{Results and discussion}

\section{Europe}

To its eastern boundary at the Ural mountains, the continent represents an area of ca. 10.18 million $\mathrm{km}^{2}$ and houses a currently slightly declining population of about 740 million (2011) with a density of 76 people per square kilometre. Climatologically, the spectrum reaches from the subarctic (low population density) to the Mediterranean space (higher population density) with an emphasis on the temperate humid climate (highest population density). Various cambisols and podsols dominate the soil types. The land-use is defined by forestry (ca. 40\%) and agriculture (ca. 40\%), with strong sub-regional heterogeneities (e.g., agriculture $2.2 \%$ on the Faroe Islands to $75.6 \%$ in Moldavia; Worldbank [1]). Population density and its consequences on land-use increased in various steps since the Bronze Age; 4,000 years ago. Today, the human population stagnates and is sub-regionally slightly decreasing. Locally highly restricted "hot spots" of soil and sediment contamination evolved as of the Bronze Age, visible even on continental scale geochemical maps [3]. Almadén (Spain), Goslar (Germany) and SW-Wales (Great Britain) may serve as related examples; partly noticeable in Figure 1. Source for each of these anomalies are rich mineralisations with local mining and smelting activities. Even without the human activities, positive anomalies would be detectable - albeit even more spatially focussed; mining and smelting have often contributed to a higher spread and to increased surface concentrations.

The official (proven) history of mining in the Erzgebirge [ore mountains] began in Carolingian times $\left(9^{\text {th }}\right.$ Century AD; $[6,7])$. Latest starting in the $12^{\text {th }}$ Century, extensive base metal, tin and silver deposits led to a fast regional development that persisted with various interruptions into the $20^{\text {th }}$ Century. Today, and due to the global market prices and the demand for metallic resources, another renaissance emerges [8,9]. Centuries of mining and smelting activities, mostly without any environmental protection technologies, as we know them today, led to a radical alteration of (sub-) local pedogeochemistry with anomalies that may exceed local geogenic background values by several orders of magnitude [10]. For a long time, the city of Freiberg was referred to in popular parlance as $\mathrm{ABC}$-city: in short for the complex soil pollution with arsenic $(\mathrm{A})$, lead $(\mathrm{Pb}=\mathrm{B})$ and cadmium $(C)$; see Figure 2.

This contamination is not area-representative, however - neither for Saxony and Germany, nor for Europe [3]. The contamination must not even be dangerous or threatening - here, the chemical (and mineral) bond of the potentially toxic elements defines the risks involved. It is critical whether the dispersion of the positive anomaly leads to an increased bioavailability that permits a 


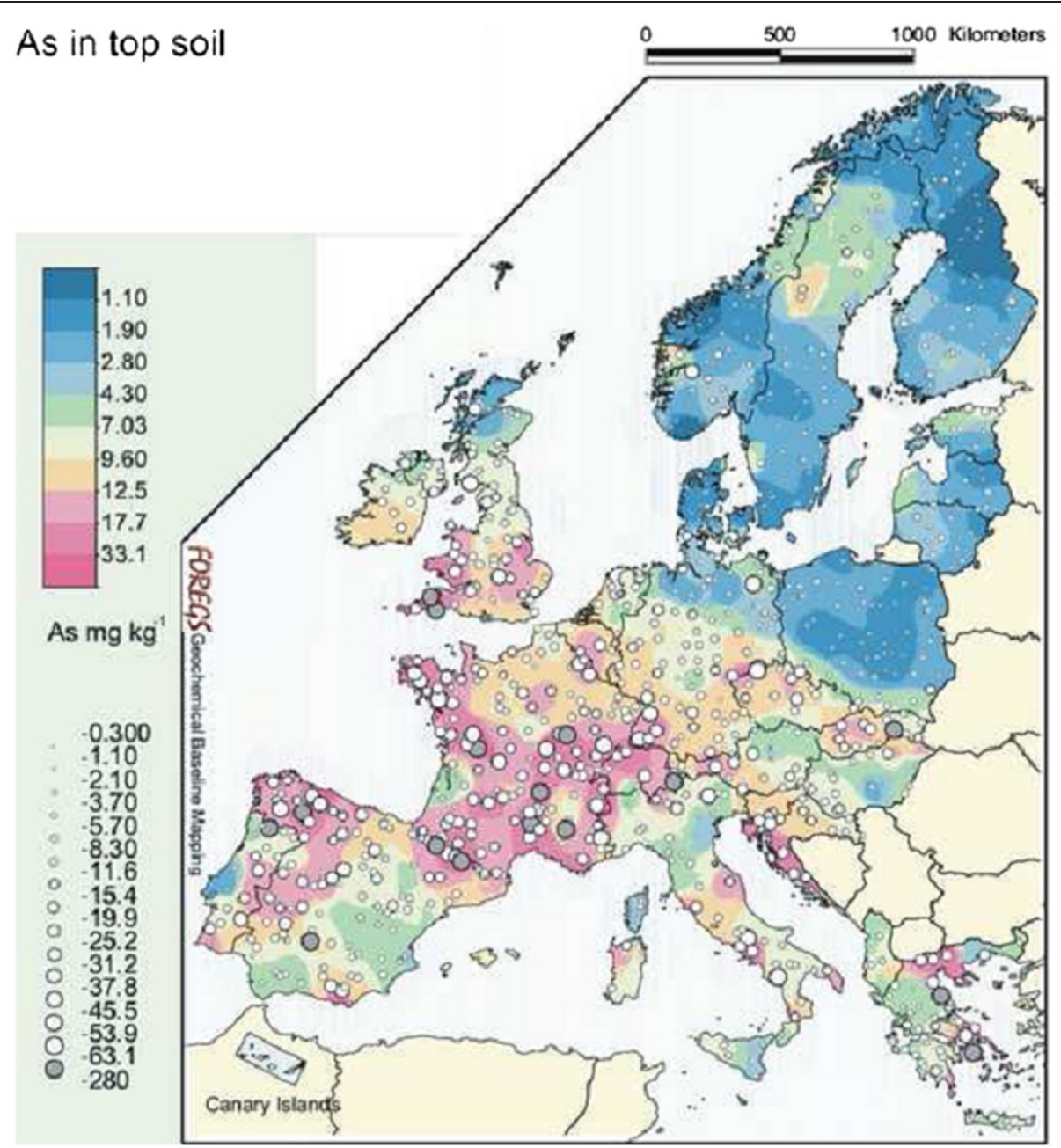

Figure 1 Arsenic in European topsoil (from [3]: 119).

toxicologically relevant input of toxins within relatively short time increments (fluxes) into the food chain or surface waters and groundwaters, or the risk of direct skin contact and geophagy. The dominant climatological conditions with still more or less regularly distributed annual precipitation and a closed vegetation cover for much of the year additionally slow down the mobility and dispersion of potentially toxic compounds. A closer look as soil geochemical data demonstrates that geological forces shape the concentrations and occurrence patterns of the elements - even in densely populated (e.g., Berlin) and highly industrialised Central Europe [3]. In large cities such as Berlin, there are certainly (and partly relevant) human-induced positive anomalies. At the same time, background values do occur even in the inner city environment and they dominate the city perimeter. The hypothesis is that the distribution patterns of European soil chemistry - at least when investigated on a continental scale - is dominated by the Quaternary glacial history in the northern half of Europe, and even
Tertiary processes in its southern half [11-14]. Such influence of the Quaternary climate history (and partly older) with its coupled geological and pedological consequences is equally applicable to vast areas of the northern hemisphere, mainly Russia, the northern part of the USA and Canada.

\section{Brazil}

The country has continental dimensions with its area of $8.51 \mathrm{Mio} . \mathrm{km}^{2}$. The current population number amounts to about 192 million (2011) with a density of 22 people per square kilometre. Most of the country is subject to tropical, in its south partly subtropical conditions. Different from Europe, these climates prevailed also during the Quaternary. Oxisols and ferralsols as well as podsols dominate the country's soil cover. Its land-use has experienced radical changes as of post-Columbian times; the last 512 years. Agricultural production prevails over ca. $31 \%$ of the area, near natural forest covers about $27 \%$ of the country; the total forested area amounts to $55 \%$ 


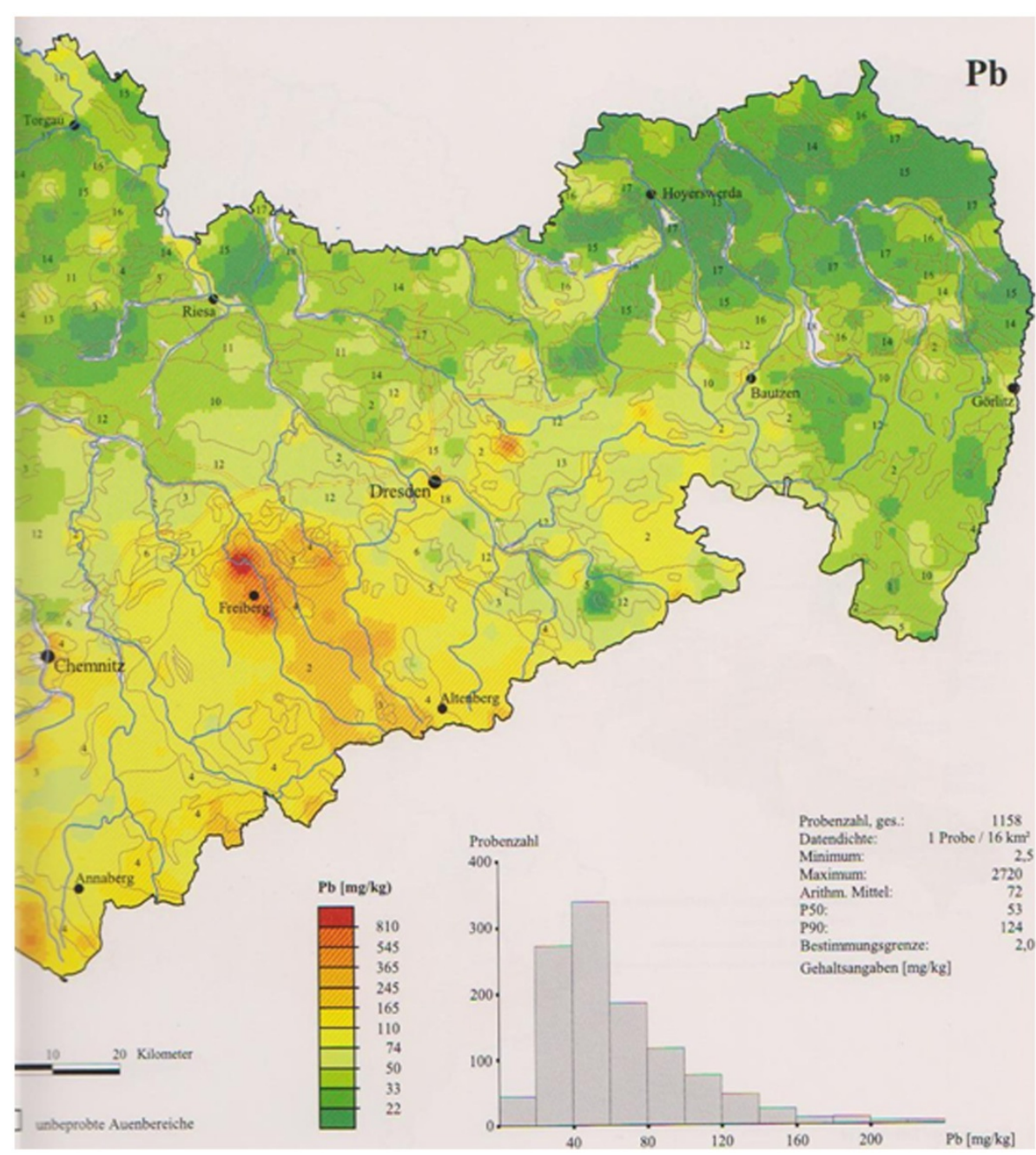

Figure 2 Lead $(\mathrm{Pb})$ in mineral topsoil in Saxony, Germany (Rank et al. 1997: detail from the map 4.10-2).

(Worldbank [1]). The rather small share in agricultural land-use is explained by the large share of the semi-arid Caatinga biome in the Northeast with dominating extensive agriculture (mainly cattle ranching). Nevertheless, livestock farming is responsible for decreasing forest area in originally pristine forests in the neighbouring Cerrado biome.

The biomes Amazon Rainforest, Atlantic coastal forest (Mata Atlântica), Cerrado forests, Caatinga savanna and Pampa grasslands were from all probability and evidence under a very low human influence prior to European colonisation. Today, all of them are partly strongly influenced and have lost their biome character in some sub-regions [15]. This is particularly eminent for the Atlantic forest, since the coast of Brazil was the focus of European settling and development activities [16]. The indigenous population showed a very low population density [16] and had adapted to the mostly very nutrient poor soils (Table 3 ). Mining and smelting started very slowly in the late $16^{\text {th }}$ Century [17]. The development of natural (mineral) resources advances very fast as of the 1950's and forms the base for the strong economic and social development of Brazil. Starting in the "Iron Quadrangle" in the state of Minas Gerais, relevant activities are abound in most of the 27 states between Roraíma and Amapá (N) to Rio Grande do Sul (S). The related economic growth and the recently very rapidly increasing consumption of a growing population are reflected in the development of the country's megacities and infrastructures.

This change that encompasses the development of industrial agriculture, takes place on soils that are partly several tens of millions of years old. Soils that - different from those in Europe and North America have left behind their state of maturity and which are partly decoupled from their bedrock lithogeochemistry $[11,19,20]$.

The biomes have adapted in an evolutionary manner to regional element cycles and carry voluptuous vegetation wherever enough water is available - despite very low nutrient availability. Yet this constellation challenges 
Table 2 Concentration ranges of selected trace elements from European soils and surface waters (total concentrations from [3]) and in ground waters (Reimann and Birke 2010; *here 95 percentile)

\begin{tabular}{|c|c|c|c|c|c|c|}
\hline Element & Medium & Minimum & Median & 90 Percentile & Maximum & $N$ \\
\hline \multirow[t]{4}{*}{$\overline{\text { As }}$} & topsoil & 0.32 & 7.03 & 22.9 & 282 & 840 \\
\hline & subsoil & 0.22 & 6.02 & 22.0 & 593 & 783 \\
\hline & surface water & $<0.01$ & 0.63 & 2.45 & 27.3 & 807 \\
\hline & groundwater & $<0.03$ & 0.235 & 5.15 & 89.8 & 884 \\
\hline \multirow[t]{4}{*}{$\mathrm{Cd}$} & topsoil & $<0.01$ & 0.145 & 0.48 & 14.1 & 840 \\
\hline & subsoil & $<0.01$ & 0.09 & 0.31 & 14.2 & 783 \\
\hline & surface water & $<0.002$ & 0.01 & 0.053 & 1.25 & 807 \\
\hline & groundwater & $<0.003$ & 0.003 & 0.037 & 1.13 & 884 \\
\hline \multirow[t]{4}{*}{$\mathrm{Cr}$} & topsoil & $<3.0$ & 60.0 & 122 & 6,230 & 845 \\
\hline & subsoil & 3.0 & 62.0 & 129 & 2,140 & 787 \\
\hline & surface water & $<0.01$ & 0.38 & 1.4 & 43.0 & 806 \\
\hline & groundwater & $<0.2$ & $<0.2$ & 1.47 & 27.2 & 884 \\
\hline \multirow[t]{4}{*}{$\mathrm{Cu}$} & topsoil & 0.81 & 13.0 & 34.0 & 256 & 840 \\
\hline & subsoil & 0.86 & 13.9 & 34.8 & 125 & 783 \\
\hline & surface water & 0.08 & 0.88 & 2.45 & 14.6 & 808 \\
\hline & groundwater & $<0.1$ & 0.272 & 4.66 & 99.7 & 884 \\
\hline \multirow[t]{4}{*}{$\mathrm{Mn}$} & topsoil & 0.004 & 0.065 & 0.155 & 0.778 & 845 \\
\hline & subsoil & 0.003 & 0.06 & 0.143 & 0.604 & 788 \\
\hline & surface water & $<0.05$ & 15.9 & 132 & 3,010 & 804 \\
\hline & groundwater & $<0.1$ & 0.5 & 249 & 1,870 & 884 \\
\hline \multirow[t]{4}{*}{$\mathrm{Ni}$} & topsoil & $<2.0$ & 18.0 & 49.8 & 2,690 & 843 \\
\hline & subsoil & $<2.0$ & 21.8 & 58.5 & 2,400 & 790 \\
\hline & surface water & 0.03 & 1.91 & 4.72 & 24.6 & 807 \\
\hline & groundwater & $<0.02$ & 0.18 & 4.34 & 94.6 & 884 \\
\hline \multirow[t]{4}{*}{$\mathrm{Pb}$} & topsoil & 5.3 & 22.6 & 51.1 & 970 & 843 \\
\hline & subsoil & $<3.0$ & 17.2 & 36.4 & 938 & 790 \\
\hline & surface water & $<0.005$ & 0.093 & 0.43 & 10.6 & 807 \\
\hline & groundwater & $<0.01$ & 0.016 & 0.315 & 2.29 & 884 \\
\hline \multirow[t]{4}{*}{$\mathrm{Zn}$} & topsoil & $<3.0$ & 52.0 & 111 & 2,900 & 845 \\
\hline & subsoil & $<3.0$ & 47.0 & 107 & 3,060 & 788 \\
\hline & surface water & 0.09 & 2.68 & 10.2 & 310 & 807 \\
\hline & groundwater & $<0.2$ & 0.89 & 19.1 & 651 & 884 \\
\hline
\end{tabular}

Solids in $\mathrm{mg} \mathrm{kg}^{-1}$, water in $\mu \mathrm{g} \mathrm{L}^{-1}$.

The selected data were taken without any modification from the original sources. These elements represent both potential pollutants and a very heterogeneous behaviour in soils and waters (redox, pH-conditions, fraction of organic substance).

the modern agricultural practice and human adaptive capacities if sustainable land-use is to be achieved despite the unfavourable boundary conditions (nutrient, humus). This challenge appears much more demanding than the often-negative consequences of locally intense mining and ore processing activities that leaves, similar to North America and Europe a strictly local "footprint" - with problems analogue to those described above.

\section{Conclusions}

The term "soil protection" is per se rather imprecise similar to the terms species protection, water protection and climate protection. To develop an appropriate and sustainable soil protection (strategy), an initial and thorough investigation of the soil status is needed, including the explanation why the current status is the way it is and which processes were and are responsible. This is true for any spatial scale; yet a local or even spot analysis may require modified methods as compared to a regional or continental approach. Neither of these points is currently common practice, as numerous examples have shown, including the North American and European forest decline story of the 1970's and 1980's. The required knowledge is a non-negotiable base for any 
Table 3 Median values and ranges (except for WSA) of major, minor (wt-\%) and selected trace elements (mg kg ${ }^{-1}$ ) in surface mineral soils: World Soil Average (WSA), BraSol 2010, NGSA, FOREGS*

\begin{tabular}{|c|c|c|c|c|}
\hline & WSA & BraSol & NGSA & FOREGS \\
\hline $\mathrm{SiO}_{2}$ (wt.-\%) & 28.0 & 2.26 (31.45-99.8) & $77.5(0.75-99.0)$ & $67.7(1.47-96.7)$ \\
\hline $\mathrm{Al}_{2} \mathrm{O}_{3}(\mathrm{wt} .-\%)$ & 8.0 & $9.02(0.61-31.2)$ & $8.08(0.17-28.0)$ & $11.0(0.37-26.7)$ \\
\hline $\mathrm{Fe}_{2} \mathrm{O}_{3}$ (wt.-\%) & 3.5 & $1.72(0.08-21.16)$ & $3.22(0.10-32.8)$ & $3.51(0.16-22,3)$ \\
\hline $\mathrm{CaO}$ (wt.-\%) & 1.4 & $0.05(0.008-3.1)$ & $0.45(0.03-51.2)$ & $0.92(0.026-47.7)$ \\
\hline MgO (wt.-\%) & 0.9 & $0.039(0.01-2.37)$ & $0.50(0.01-9.0)$ & $0.77(<0.01-24.6)$ \\
\hline $\mathrm{K}_{2} \mathrm{O}(w t .-\%)$ & 1.4 & $0.14(0.005-5.70)$ & $1.19(<0.01-4.4)$ & $1.92(0.026-6.13)$ \\
\hline $\mathrm{Na}_{2} \mathrm{O}($ wt.-\%) & 1.0 & $0.023(0.003-3.24)$ & $0.30(<0.005-5.79)$ & $0.80(0.04-4.45)$ \\
\hline $\mathrm{Ba}\left(\mathrm{mg} \mathrm{kg}^{-1}\right)$ & 500 & $55.9(7.5-4590)^{*}$ & $315(4-2,577)$ & $375(30-1,870)$ \\
\hline $\mathrm{Ce}\left(\mathrm{mg} \mathrm{kg}^{-1}\right)$ & 65 & $37.3(32.4-421)$ & $42(1-252)$ & $48.2(2.45-267)$ \\
\hline $\mathrm{Cr}\left(\mathrm{mg} \mathrm{kg}^{-1}\right)$ & 80 & $33.8(5-188)$ & $48(5-2,039)$ & $60(<3.0-6,230)$ \\
\hline $\mathrm{Cu}\left(\mathrm{mg} \mathrm{kg}^{-1}\right)$ & 25 & $12.9(5-35.7)$ & $11(0.01-150)^{\#}$ & $13(0.81-256)$ \\
\hline $\mathrm{Mn}\left(\mathrm{mg} \mathrm{kg}^{-1}\right)$ & 530 & $75.1(5-1240)$ & $279(0.5-3,740)^{\#}$ & $500(3-6,000)$ \\
\hline$P\left(\mathrm{mg} \mathrm{kg}^{-1}\right)$ & 750 & $185(94-1620)$ & $266(52.4-2,444)$ & $559(48-5,760)$ \\
\hline $\mathrm{Pb}\left(\mathrm{mg} \mathrm{kg}^{-1}\right)$ & 17 & $5.0(5.0-60)$ & $13(0.5-1,530)$ & 22.6 (5.3-970) \\
\hline $\mathrm{Rb}\left(\mathrm{mg} \mathrm{kg}^{-1}\right)$ & 65 & $13.1(12.6-271)$ & $51(0.1-269)$ & $80(<2.0-390)$ \\
\hline $\mathrm{S}\left(\mathrm{mg} \mathrm{kg}^{-1}\right)$ & 800 & $57(12.5-817)$ & Keine Daten & $227(<50-112,000)$ \\
\hline $\mathrm{Sr}\left(\mathrm{mg} \mathrm{kg}^{-1}\right)$ & 240 & $24.5(5-1590)$ & $68(1-6,459)$ & $89(8.0-3,120)$ \\
\hline $\mathrm{Ti}\left(\mathrm{mg} \mathrm{kg}^{-1}\right)$ & 4000 & $3065(332-12,400)$ & $3,500(108-30,694)$ & $3,429(126-32,673)$ \\
\hline$V\left(\mathrm{mg} \mathrm{kg}^{-1}\right)$ & 90 & $37.6(5-357)$ & $55(0.1-586)$ & $60.4(2.71-537)$ \\
\hline $\mathrm{Zn}\left(\mathrm{mg} \mathrm{kg}^{-1}\right)$ & 70 & $11.5(5-113)$ & $31(<0.9-210)$ & $52(<3.0-2,900)$ \\
\hline $\operatorname{Zr}\left(\mathrm{mg} \mathrm{kg}^{-1}\right)$ & 230 & 387 (92-3860) & $304(4-1,778)$ & $231(5.0-1,060)$ \\
\hline
\end{tabular}

*WSA: Koljonen [18]; BraSol: Schucknecht et al. [19], the lower limit of determination for Ba was $15 \mathrm{mg} \mathrm{kg}^{-1}$, for all other trace elements $10 \mathrm{mg} \mathrm{kg}^{-1}$ (pressed powder pellets, WD-XRF); NGSA: Reimann et al. [14]; FOREGS: Salminen et al. [3]. "aqua regia extraction.

type of measure to improve or preserve e.g., soil fertility, or to allow for a desired land-use over extended periods of time (human generations). Depending of the defined goals and the objective necessities, consequences and boundary conditions emerge that allow the decision makers to trigger meaningful measures and activities.

Starting with the initially formulated hypothesis, the given examples (and many others) demonstrate that anthropogenic soil pollution does not occur ubiquitously and that even in densely populated areas (e.g., Berlin) such pollution may be negligible on a sub-local level (e.g., large individual property, city block). Such insight eases the distinct identification of truly contaminated areas that may then be treated appropriately. Such action may reach from rather inexpensive withdrawal from common use to partly very expensive remediation. Soils of different climate zones and regions significantly differ in their geochemistry (and their ages and thus their history). Thus simplifying global average values (such as WSA) is of limited if any value or even misleading for almost any concrete situation. This is similarly true for the uncritical and un-adapted use of threshold or limit values and related environmental standards. Their application appears meaningful under the fulfilment of three boundary conditions only: i) the values are adapted to a defined space, for which the respective directive or law has been formulated; ii) the values will include the potential and real mobility of the related elements and thus their bioavailability (binding forms, redox and $\mathrm{pH}$-conditions); and iii) the values will not be statistically defined for larger areas (see i), but are exclusively based on toxicological evidence. The latter presents a major challenge and effort, yet it should, e.g., applied to a country like Germany, demand in total a lot of superfluous work and costs, and will thus permit much more targeted and efficient solutions.

\section{Competing interests}

The author declare that they have no competing interests.

\section{Acknowledgements}

Peter Beuge was a full professor for Geochemistry at the Institute of Mineralogy at TU Bergakademie Freiberg. He died prematurely, fighting a terminal cancer. The title stems from his words. He always tried to go "behind the scenes" of any issue and to pose the truly relevant questions instead of the "politically correct" ones. Thanks go to Alexander Pleßow, Clemens Reimann and Eleonora Deschamps for their critical comments to a previous version of this paper, to Gerald Schmidt for opening the door to this journal and to various colleagues from the International Geochemical Mapping Programme, whose most constructive criticism and valuable suggestions over the years have certainly influenced my own thinking. 


\section{References}

1. Worldbank: 2011. http://data.worldbank.org/topic (Last access 06.09.2012).

2. Montgomery DR: Dirt. The erosion of civilizations. Berkeley: University of California Press; 2010:285.

3. Salminen R, Batista MJ, Bidovec M, Demetriades A, De Vivo B, De Vos W, Duris M, Gilucis A, Gregorauskiene V, Halamic J, Heitzmann P, Lima A, Jordan G, Klaver G, Klein P, Lis J, Locutura J, Marsina K, Mazreku A, O'Connor P, Ottesen RT, Plant JA, Reeder S, Salpeteur I, Sandström H, Siewers U, Steenfelt A, Tarvainen T: FOREGS Geochemical Atlas of Europe. In Part 1: Background information, methodology and maps. Espoo: Geol Survey Finland; 2005:526.

4. Caritat P, Cooper M: National Geochemical Survey of Australia: The Geochemical Atlas of Australia:: Geoscience Australia GeoCat 71973; 2011.

5. Matschullat J: Leben in außergewöhnlichen Konzentrationen (ein Tribut an Peter Beuge). Forum Geoökologie 2011, 22(3):10-16.

6. Baumann L, Kuschka E, Seifert T: Lagerstätten des Erzgebirges. Stuttgart: Enke Verlag; 2000. 300 p.

7. Wagenbreth O, Wächtler E, Becke A, Douffet H, Jobst W: Bergbau im Erzgebirge. Leipzig: Technische Denkmale und Geschichte. Deutscher Verlag für Grundstoffindustrie; 1990. 504 p.

8. LfULG: Sachsens Bodenschätze: Vorkommen und Verwertung. Landesamt für Umwelt. Dresden, Selbstverlag: Landwirtschaft und Geologie; 2010:28.

9. Steinbach V, Buchholz P, Elsner H, Wilken H: Verfügbarkeit von Rohstoffen mit Blick auf Zukunftstechnologien. In Energie und Rohstoffe. Gestaltung unserer nachhaltigen Zukunft. Edited by Kausch P, Bertau M, Gutzmer J, Matschullat J. Heidelberg: Spektrum Verlag; 2011:193.

10. Rank G, Kardel K, Pälchen W, Weidensdörfer H: Bodenatlas des Freistaates Sachsen. Teil 3. Bodenmessprogramm, Bodenmeßnetz Raster 4 x 4 km. In Sächsisches Landesamt für Umwelt und Geologie. Dresden: Materialien zum Bodenschutz; 1999:157.

11. Matschullat J, da Silva J, Höfle S, Mello J, Melo G Jr, Plessow A, Reimann C: A soil geochemical baseline for north-eastern Brazil. Geochem Explor Environ Anal 2012, 72(3):197-209.

12. Reimann C, Matschullat J, Birke M, Salminen R: Arsenic distribution in the environment: the effects of scale. App/ Geochem 2009, 24(7):1147-1167.

13. Reimann C, Matschullat J, Birke M, Salminen R: Antimony in the environment: lessons from geochemical mapping. App/ Geochem 2010 25(2):175-198.

14. Reimann C, de Caritat P, EuroGeoSurveys GEMAS Project Group: New soil composition data for Europe and Australia: demonstrating comparability, identifying continental-scale processes and learning lessons for global geochemical mapping. Sci Total Environ 2011, 416:239-252.

15. Schmidt N, Geier P, Mannschatz T, Matschullat J: The cerrado biome in central Brazil - natural ecology and threats to its diversity. Forum Geoökologie 2009, 20(2):44-50.

16. Simielli MER: Geoatlas. São Paulo: Editora ática; 2007:168.

17. Meneses I, Renger F, Deschamps E: History and socioeconomy. In Arsenic: natural and anthropogenic. Edited by Deschamps E, Matschullat J. Leiden: CRC Press/Balkema; 2011:73-80.

18. Koljonen T: The geochemical atlas of Finland. Part 2: Till. Espoo, Finland: Geological Survey of Finland; 1992:218.

19. Schucknecht A, Matschullat J, de Caritat P, Melo G, Mello J, Plessow A, da Silva J: Pedogeochemistry in NE-Brazil, compared to Australia and Europe. Sci Total Environ 2012, 438:342-356. doi:10.1016/j.scitotenv.2012.08.059.

20. Schucknecht A, Matschullat J, Reimann C: Lead (Pb) and stable Pb-isotope characteristics of tropical soils in north-eastern Brazil. Appl Geochem 2011, 26(12):2191-2200.

doi:10.1186/2190-4715-24-25

Cite this article as: Matschullat: Life in extraordinary concentrations

(a tribute to Peter Beuge). Environmental Sciences Europe 2012 24:25. 